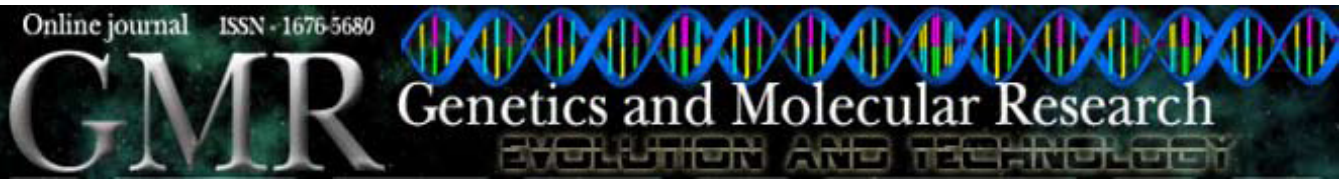

\title{
Molecular characterization of olive cultivars using amplified fragment length polymorphism markers
}

\author{
S. Ercisli ${ }^{1}$, E. Barut ${ }^{2}$ and A. Ipek ${ }^{2}$ \\ ${ }^{1}$ Department of Horticulture, Faculty of Agriculture, Erzurum,Turkey \\ ${ }^{2}$ Department of Horticulture, Faculty of Agriculture, Gorukle, Bursa, Turkey \\ Corresponding author: S. Ercisli \\ E-mail: sercisli@hotmail.com
}

Genet. Mol. Res. 8 (2): 414-419 (2009)

Received January 20, 2009

Accepted March 4, 2009

Published April 14, 2009

\begin{abstract}
We sampled six olive cultivars (Tavli Sati, Sati, Gorvela, Sacakli Otur, Butko, and Otur) from Coruh Valley, located in the northeast part of Turkey, and characterized them using amplified fragment length polymorphism (AFLP) markers. Some morphological and biochemical characteristics are also determined. Six AFLP primer combinations were used for molecular characterization and 66 AFLP markers were obtained. Six olive cultivars were classified into two major clusters using UPGMA clustering analysis; cv. Otur alone comprised the first group. Some morphological and biochemical characteristics of cv. Otur were also distinct from those of the other cultivars. The highest genetic similarity was observed between cultivars Tavli Sati and Sati (0.74), while the lowest genetic similarity was observed between cvs. Gorvela and Otur (0.37).
\end{abstract}

Key words: Olive; Amplified fragment length polymorphism;

Molecular markers 


\section{INTRODUCTION}

The olive tree (Olea europaea L.) is one of the most important fruit trees in the Mediterranean countries. Their products, olive oil and table olives, are important components of the Mediterranean diet and are greatly consumed in the world. The Mediterranean region is the major international olive-growing area, accounting for almost $95 \%$ of the world's olive tree planting. The biggest olive-producing countries in the Mediterranean region are Spain, Italy, Greece, and Turkey. Although Turkey is the fourth country in the production of fresh olives, it is the second greatest producer in the world for table olives after Spain (Anonymous, 2006). In order of production levels in Turkey, black table olives account for the highest followed by the green and kalamata type olives (Ünal and Nergiz, 2003).

Olives have great commercial importance in Turkey. They are used for local table consumption as well as oil and soap production. Turkey is also one of the important olive oil exporters. Olive growing in Turkey is well established mainly around the Aegean and Mediterranean regions, but also in the Marmara, Southeastern Anatolia and Black Sea regions (Mendilcioglu, 2001).

The Coruh Basin near the Black Sea Region is one of the most spectacular nature reserves in Turkey. With its rich biological diversity, the Coruh Valley is one of the 35 world hotspots of biodiversity pointed out by the World Conservation Union, where it makes up the western section of "Caucasus Ecosystem" (Anonymous, 2007). Its rich biological diversity, in particular for subtropical fruits including olives, is a result of the extreme variations in climate within a very small area.

Olive cultivars are quite diverse both in external and internal fruit characteristics such as size, shape, color, texture, oil ratio, oil composition, etc. Plant characteristics are also very diverse, ranging from shrubs to large trees, extending to upright, and having small to large leaves (Mendilcioglu, 2001; Anonymous, 2005).

Olive cultivars are generally identified by morphological traits including tree, fruit and leaf characteristics (Aydin and Yunculer, 1983; Canözer, 1991; Kaya and Tekintas, 2006). However, as in many out crossing crops, olive cultivars are highly heterozygous, with most of their morphological, physiological and biochemical traits showing continuous variation and high plasticity. Similarly, most morphological traits are influenced by environmental factors, plant age and phenology. Since objectivity is crucial for accurate morphological typing, the above factors render the use of such traits in plant identification and discernment of genetic relationships difficult (Ercisli et al., 2008). The introduction of DNA-based markers provides an opportunity for genetic characterization that allows direct comparison of different genetic materials independent of environmental influences. DNA-based markers are a useful tool for plant scientists in establishing phylogenies, tagging desirable genes, determining similarities among in-breeding materials, and mapping plant genomes (Li et al., 2001).

Amplified fragment length polymorphisms (AFLP) constitute a highly reproducible multi-locus marker system developed by Vos et al. (1995). High levels of polymorphism and high degrees of discriminative capacity are the main advantages of AFLP for closely related accessions. Although the AFLP method has been used to identify genetic relationships among olive cultivars throughout the world (Dunja et al., 2004; Owen et al., 2005; Montemurro et al., 2005), the use of this method to determine genetic relationships between cultivars natively grown in Turkey has been limited. The objectives of this study were to characterize 6 cultivars of olive that are grown in Turkey. 


\section{MATERIAL AND METHODS}

\section{Plant material}

Six olive cultivars were used for molecular analysis: "Tavli Sati”, "Sati”, "Gorvela", "Sacakli Otur", "Butko", and "Otur". The accessions were found together in a Zeytinlik village in Coruh Valley in Turkey. Some morphological and biochemical characteristics of the cultivars are given in Table 1.

\begin{tabular}{lllllll}
\multicolumn{6}{l}{ Table 1. Some morphological and biochemical characteristics of olive cultivars from Turkey. } \\
\hline Cultivar & Tree growth habit & Fruit size & Flesh ratio & Fruit shape & Leaf size & Oil content \\
\hline Tavli Sati & Semi-upright & Small & High & Cylindrical & Small & High \\
Sati & Semi-upright & Small & Medium & Cylindrical & Small & Medium \\
Gorvela & Semi-upright & Small & High & Ovate & Medium & Low \\
Sacakli Otur & Upright & Medium & Low & Elliptical & Large & Low \\
Butko & Upright & Small & Medium & Cylindrical & Large & High \\
Otur & Upright & Large & Low & Elliptical & Large & Low \\
\hline
\end{tabular}

\section{DNA extraction and AFLP analysis}

DNA samples were extracted from lyophilized powdered young leaves of each genotype. For this purpose, $150 \mathrm{mg}$ powdered leaf samples was used for DNA extraction in microcentrifuge tubes following a modified CTAB protocol described by Futterer et al. (1995). The phenol-chloroform extraction method of DNA was used to increase the purity of DNA for AFLP analysis. The concentration of each DNA sample was determined and adjusted to $50 \mathrm{ng} / \mu \mathrm{L}$ for analysis.

The AFLP procedure was carried out according to methods described previously by Vos et al. (1995) using AFLP system I (Invitrogen). Briefly, after digestion of 300 ng genomic DNA with $M s e I$ and EcoRI enzymes, MseI and EcoRI restriction-site derived adapters were ligated to DNA fragments. Pre-amplification was performed using pre-amplification primers (EcoRI-A/MseI-C), and the polymerase chain reaction products of pre-amplification reactions were diluted 50X to use in selective amplification as a template DNA.

Six $M s e I(M)$ and EcoRI (E) selective amplification primer combinations with three selective nucleotides $\left(\mathrm{E}_{\mathrm{AGC}} / \mathrm{M}_{\mathrm{CTG}}, \mathrm{E}_{\mathrm{AGC}} / \mathrm{M}_{\mathrm{CTC}}, \mathrm{E}_{\mathrm{ACG}} / \mathrm{M}_{\mathrm{CTG}}, \mathrm{E}_{\mathrm{ACG}} / \mathrm{M}_{\mathrm{CTC}}, \mathrm{E}_{\mathrm{ACC}} / \mathrm{M}_{\mathrm{CTG}}, \mathrm{E}_{\mathrm{ACC}} / \mathrm{M}_{\mathrm{CTC}}\right)$ were used for selective amplification of AFLP markers. Selective amplification product was denatured and size fractionated on $6 \%$ acrylamide gels by running for $2 \mathrm{~h}$ and $30 \mathrm{~min}$ at $60 \mathrm{~W}$. AFLP markers were visualized by silver-staining of DNA fragments and photographed.

\section{Data analysis}

All unambiguous polymorphic AFLP markers were identified and scored as present (1) or absent (0). The similarity matrix among the six olive cultivars, calculated using the Dice coefficient (Dice, 1945), was utilized to construct an unweighted pair-group method of arithmetic average cluster analysis (UPGMA) using NTSYSpc version 2.11V (Exeter Software, Setauket, NY) (Rohlf, 2004). 


\section{RESULTS AND DISCUSSION}

Table 2 summarizes the data generated by the 6 AFLP primers. A total of 66 AFLP markers were obtained using 6 AFLP primer-enzyme combinations. The primer $\mathrm{E}_{\mathrm{ACC}} / \mathrm{M}_{\mathrm{CTG}}$ generated the highest number of AFLP markers (15), followed by $\mathrm{E}_{\mathrm{ACG}} / \mathrm{M}_{\mathrm{CTC}}(13), \mathrm{E}_{\mathrm{AGC}} / \mathrm{M}_{\mathrm{CTC}}$ (12), $\mathrm{E}_{\mathrm{ACC}} / \mathrm{M}_{\text {СтC }}(11), \mathrm{E}_{\mathrm{AGC}} / \mathrm{M}_{\mathrm{CTG}}$ (9), and $\mathrm{E}_{\mathrm{ACG}} / \mathrm{M}_{\text {СТG }}$ (6). Of the 141 bands detected, 66 were polymorphic with a $47 \%$ polymorphism ratio.

\begin{tabular}{lc} 
Table 2. Number of amplified fragment length polymorphism (AFLP) markers in the DNA fingerprinting of \\
olive accessions from Turkey. \\
\hline AFLP primer combination & Number of AFLP markers \\
\hline $\mathrm{E}_{\mathrm{AGC}} / \mathrm{M}_{\mathrm{CTG}}$ & 9 \\
$\mathrm{E}_{\mathrm{ACC}} / \mathrm{M}_{\mathrm{CTC}}$ & 12 \\
$\mathrm{E}_{\mathrm{ACG}} / \mathrm{M}_{\mathrm{CTG}}$ & 6 \\
$\mathrm{E}_{\mathrm{ACG}} / \mathrm{M}_{\mathrm{CTC}}$ & 13 \\
$\mathrm{E}_{\mathrm{ACC}} / \mathrm{M}_{\mathrm{CTG}}$ & 15 \\
$\mathrm{E}_{\mathrm{ACC}} / \mathrm{M}_{\mathrm{CTC}}$ & 11 \\
Total & 66 \\
\hline
\end{tabular}

AFLP markers have been previously used in genetic diversity and relationship studies in olive cultivars. Owen et al. (2005) sampled 65 olive genotypes including most of the important cultivars from Turkey, Greece and the Middle East and selected genotypes from the western Mediterranean area. They obtained a total of 119 polymorphic markers generated from five selective AFLP primer-pair combinations, which resulted in a $41.5 \%$ polymorphism ratio. The combined data sets generated by just two primer pairs were adequate to discriminate all 65 genotypes. Sensi et al. (2003) characterized a total 12 olive cultivars originating in Italy using AFLP markers. AFLP analysis of 12 cultivated olive accessions using six pairs of primers provided a total of 274 markers. One hundred and sixty-four of these loci (59.8\%) were polymorphic over all the genotypes tested. The total number of polymorphic bands over all populations detected by individual primer pair varied from 13 (for primer combination No. 3 ) to 40 (for primer combination No. 1). The primer combinations differed in their ability to detect polymorphism within populations. Grati-Kamoun et al. (2006) characterized 29 olive (Olea europaea L.) cultivars including oil and table olive cultivars originating from Tunisia and other Mediterranean countries using AFLP markers. Using nine AFLP primer combinations, they produced a total of 410 AFLP markers, among which 172 revealed polymorphism. The results demonstrated a high degree of polymorphism in the olive germplasm with an average of $39 \%$. When compared with the above reported findings, we can say that the polymorphism ratio observed among the 6 olive cultivars investigated here is close to that of these studies and even higher than in some of these studies. In fact, the 6 cultivars studied here were found in a very restricted area, namely Coruh Valley, and the high polymorphism ratio could be important in using them in future breeding studies.

The dendrogram derived from an UPGMA cluster analysis of the AFLP markers is shown in Figure 1. Two main distinct groups were observed in the dendrogram. Group I consisted of only cultivar Otur. This cultivar was also found to be very distinct according to its morphological and biochemical data (Table 1). For example, among the six cultivars used, cv. 
Otur has the highest fruit weight value. This cultivar also has low fruit flesh ratio. The fruit shape of this cultivar is elliptical (Table 1). Therefore, there were some degrees of similarities among molecular, morphological and biochemical data within cv. Otur. Group 2 consisted of 4 subclusters. In group 2, cultivars Sati and Tavli Sati clustered together with a very high similarity ratio (0.74) (Figure 1). In fact these two cultivars have similar fruit characteristics; for example, both cultivars have small, cylindrical fruits, and the leaf size of these cultivars is small. Among the cultivars studied, the lowest genetic similarity was observed between cvs. Gorvela and Otur (0.37) (Table 3).

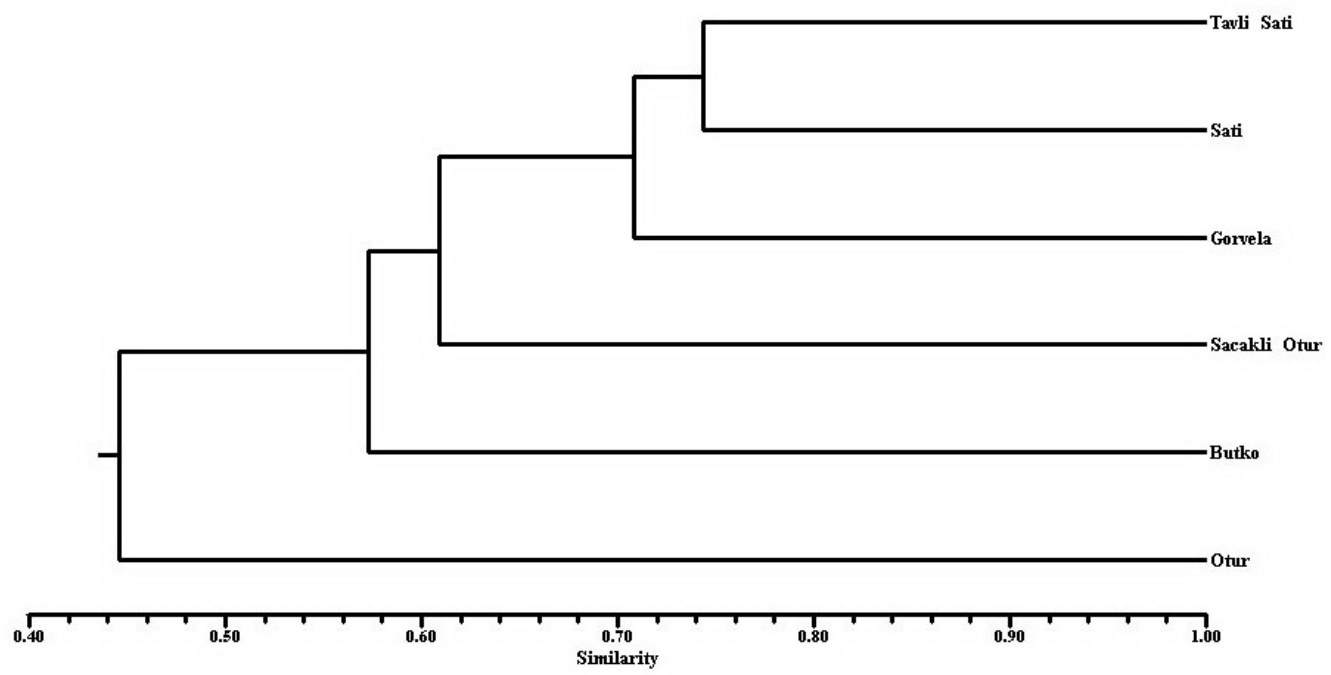

Figure 1. UPGMA dendrogram based on Dice similarity matrix obtained using 66 amplified fragment length polymorphism markers and illustrating the relative similarity among 6 olive cultivars.

Table 3. Dice similarity matrix of 6 olive cultivars determined using 66 amplified fragment length polymorphism markers.

\begin{tabular}{lcccccc}
\hline & Tavli Sati & Gorvela & Sacakli Otur & Otur & Butko & Sati \\
\hline Tavli Sati & 1.00 & & & & & \\
Gorvela & 0.71 & 1.00 & & & & \\
Sacakli Otur & 0.60 & 0.56 & 1.00 & & & \\
Otur & 0.41 & 0.37 & 0.55 & 0.00 & 1.00 & 1.00 \\
Butko & 0.63 & 0.60 & 0.52 & 0.46 & 0.55 & \\
Sati & 0.74 & 0.71 & 0.67 & 0.44 & & \\
\hline
\end{tabular}

Previously, Grati-Kamoun et al. (2006) showed that the AFLP marker system was able to separate closely related olive (Olea europaea L.) accessions. Thus, our result is also in general agreement with this study. Previous studies on the relationships of the olive acces- 
sions carried out by AFLP confirmed the suitability of this molecular marker system for the diversification of olive cultivars (Angiolillo et al., 1999; Belaj et al., 2003).

In conclusion, AFLP analysis was found to be useful for the detection of genetic differences among the olive accessions from Coruh Valley in Turkey. The results of the present study may also help breeders in selecting the most diverse genotypes with similar fruit characteristics to begin crossing and selection programs. This may result in increased olive growing for fruit production.

\section{REFERENCES}

Angiolillo A, Mencuccini M and Baldoni L (1999). Olive genetic diversity assessed using amplified fragment length polymorphisms. Theor. Appl. Genet. 98: 411-421.

Anonymous (2005). Catalogue of Standard Olive Cultivars. Ministry of Agriculture of Turkey, No. 334, Ankara.

Anonymous (2006). Food and Agricultural Organisation. Available at [www.fao.org]. Accessed January 27, 2008.

Anonymous (2007). The World Conservation Union. Available at [www.iucn.org]. Accessed January 27, 2008.

Aydin R and Yunculer O (1983). Pomological Properties of Olive Cultivars Grown in Icel Province. Horticulture Research and Education Center, Publication No. 48. Erdemli, Icel.

Belaj A, Satovic Z, Cipriani G, Baldoni L, et al. (2003). Comparative study of the discriminating capacity of RAPD, AFLP, and SSR markers and of their effectiveness in establishing genetic relationships in olive. Theor. Appl. Genet. 107: 736-744.

Canözer O (1991). Olive cultivars. Ministry of Agriculture of Turkey. No. 16, Ankara.

Dice LR (1945). Measures of the amount of ecologic association between species. Ecology 26: 297-302.

Dunja B, Jernej J and Branka J (2004). Assessment of genetic variability of olive varieties by microsatellite and AFLP markers. Euphytica 136: 93-102.

Ercisli S, Orhan E, Esitken A, Yildirim N, et al. (2008). Relationships among some cornelian cherry genotypes (Cornus mas L.) based on RAPD analysis. Genet. Resour. Crop Evol. 55: 613-618.

Futterer J, Gisel A, Iglesias V, Kloti A, et al. (1995). Standard Molecular Techniques for the Analysis of Transgenic Plants. In: Gene Transfer to Plants (Potrykus I and Spangenberg G, eds.). Springer-Verlag, New York, 215-218.

Grati-Kamoun N, Mahmoud F, Rebaï A, Gargouri A, et al. (2006). Genetic diversity of Tunisian Olive Tree (Olea europaea L.) cultivars assessed by AFLP markers. Genet. Resour. Crop Evol. 53: 265-275.

Kaya $\mathrm{H}$ and Tekintas EF (2006). Characterization of the yamalak sarisi domestic olive cultivar grown in Aydin province. $A D U$ J. Agric. Fac. 3: 69-76.

Li CD, Fatokun CA, Ubi B, Singh BB, et al. (2001). Determining genetic similarities and relationships among cowpea breeding lines and cultivars by microsatellite markers. Crop Sci. 41: 189-197.

Mendilcioglu K (2001). Olive Growing Techniques. Publication No. 36. Ege University, Bornova, Izmir.

Montemurro C, Simeone R, Pasqualone A, Ferrara E, et al. (2005). Genetic relationships and cultivar identification among 112 olive accessions using AFLP and SSR markers. J. Hortic. Sci. Biotechnol. 80: 105-110.

Owen CA, Bita EC, Banilas G, Hajjar SE, et al. (2005). AFLP reveals structural details of genetic diversity within cultivated olive germplasm from the Eastern Mediterranean. Theor. Appl. Genet. 110: 1169-1176.

Rohlf FJ (2004). NTSYS-pc Numerical Taxonomy and Multivariate Analysis System. Version 2.11V. Exeter software, Setauket.

Sensi E, Vignani R, Scali M, Masi E, et al. (2003). DNA fingerprinting and genetic relatedness among cultivated varieties of Olea europaea L. estimated by AFLP analysis. Sci. Hort. 97: 379-388.

Ünal K and Nergiz C (2003). The effect of table olive preparing methods and storage on the composition and nutritive value of olives. Grasas Aceites 54: 71-76.

Vos P, Hogers R, Bleeker M, Reijans M, et al. (1995). AFLP: a new technique for DNA fingerprinting. Nucleic Acids Res. 23: 4407-4414. 